\title{
Pengaruh Motivasi Kerja dan Displin Kerja terhadap Kinerja Karyawan di Perusahaan PTPN X Pabrik Gula Lestari Kertosono
}

\section{The Influence of Work Motivation and Work Discipline on Employee Performance in PTPN X Sugar Factory Lestari Kertosono}

\author{
Nurindah Dwi Antika* \\ Program Studi Administrasi Bisnis, FISIP, UPN "Veteran" Jawa Timur \\ e-mai: 18042010003@student.upnjatim.ac.id \\ Mujita Fajar Nataraningtyas \\ Program Studi Administrasi Bisnis, FISIP, UPN "Veteran" Jawa Timur \\ e-mail: 18042010012@student.upnjatim.ac.id \\ Elok Venanda Tessa Lonikat \\ Program Studi Administrasi Bisnis, FISIP, UPN "Veteran” Jawa Timur \\ e-mail: 18042010052@student.upnjatim.ac.id \\ Jojok Dwiridotjahjono \\ Program Studi Administrasi Bisnis, FISIP, UPN “Veteran” Jawa Timur \\ e-mail: dwiridotjahjono_jojok@upnjatim.ac.id
}

\begin{abstract}
The background in this study is how important it is for a leader to apply motivation and work discipline to the company to improve the performance of its employees, because with motivation and work discipline, employees will feel responsible for all their duties. This study aims to determine the effect of work motivation and work discipline on employee performance partially, and to determine the effect of work motivation and work discipline on employee performance simultaneously. The data analysis technique used in this study is multiple linear regression analysis, using the $F$ test and $t$ test. The results of multiple linear regression show that the work motivation variable has a significant effect on employee performance. Work discipline variables have a significant effect on employee performance. And Hail F test shows that there is a significant influence between the variables of Work Motivation and Work Discipline simultaneously affect the Employee Performance of PTPN X Lestari Sugar Factory (Kertosono). The conclusion from the results of this study is that increasing employee performance cannot be separated from work motivation (needs, attitudes, abilities, payment or salary, job security, fellow workers) and work discipline (always present on time, always prioritizing attendance percentage, always obeying the hourly provisions). work, always use working hours effectively and efficiently). With high work motivation and work discipline, it will be easier to improve employee performance.
\end{abstract}

Keywords: work motivation, work discipline, employee performance.

\begin{abstract}
ABSTRAK
Latar belakang dalam penelitian ini adalah bagaimana penting seorang pemimpin dalam menerapkan motivasi dan disiplin kerja pada perusahaan untuk meningkatkan kinerja dari karyawannya, sebab dengan adanya motivasi dan disiplin kerja maka karyawan akan merasa bertanggungjawab dengan segala tugasnya. Penelitian ini bertujuan untuk mengetahui pengaruh motivasi kerja dan disiplin kerja terhadap kinerja karyawan secara parsial, dan untuk mengetahui pengaruh motivasi kerja dan disiplin kerja terhadap kinerja karyawan secara simultan. Teknik analisis data yang digunakan dalam penelitian ini adalah analisis regresi linier berganda, dengan menggunakan uji $\mathrm{F}$ dan uji t. Hasil regresi linier berganda, menunjukkan variabel motivasi kerja berpengaruh secara signifikan terhadap kinerja karyawan. Variabel displin kerja berpengaruh secara signifikan terhadap kinerja karyawan. Dan Hasil Uji F menunjukan bahwa terdapat pengaruh yang signifikan antara variabel Motivasi Kerja dan Disiplin Kerja secara simultan berpengaruh terhadap Kinerja Karyawan PTPN X Pabrik Gula Lestari (Kertosono). Kesimpulan dari hasil penelitian ini adalah meningkatnya kinerja karyawan tidak terlepas dari Motivasi Kerja (kebutuhan, sikap, kemampuan, pembayaran atau gaji, keamanan pekerjaan, hubungan sesama pekerja) dan disiplin kerja (selalu hadir tepat waktu, selalu mengutamakan persentase kehadiran, selalu mentaati ketentuan jam kerja, selalu menggunakan jam kerja dengan efektif dan efisien). Dengan tingginya motivasi kerja dan disiplin kerja yang dimiliki maka akan lebih mudah meningkatkan kinerja karyawan.
\end{abstract}

Keywords: motivasi kerja, displin kerja, kinerja karyawan.

*Corresponding author 


\section{PENDAHULUAN}

Di era modern seperti sekarang ini, banyak terjadi persaingan yang cukup ketat. Antara perusahaan satu dengan perusahaan yang lainnya. Agar bisa bersaing, maka perusahaan harus mempunyai sumber daya yang diharapkan dapat memberikan kontribusi dan berperan aktif di setiap kegiatan, sehingga hal tersebut akan berpengaruh terhadap ketercapaian dan keberhasilan di dalam perusahaan.

Motivasi merupakan suatu keinginan yang muncul dalam diri karyawan sehingga menimbulkan semangat atau dorongan untuk bekerja secara optimal guna mencapai tujuan. Berdasarkan dari penjelasan tersebut maka dapat diartikan bahwa semakin kuat motivasi seseorang, seemakin kuat pula usaha karyawan untuk mencapai tujuan perusahaan.

Displin Kerja merupakan faktor penting dalam perusahaan. Karyawan yang mempunyai disiplin kerja yang tinggi, akan bekerja sesuai dengan tanggung jawabnya tanpa harus diawasi oleh atasan. Yang artinya semakin baik disiplin karyawan, semakin tinggi prestasi kerja yang dapat dicapainya. Ukuran dalam menilai apakah pegawai tersebut disiplin atau tidak, dapat terlihat dari ketepatan waktu dalam bekerja, etika berpakaian, serta penggunaan sarana kantor secara efektif dan efisien. Dengan demikian motivasi dan disiplin kerja sangat berperan dalam menunjang kinerja kerja karyawan.

Berikut disajikan tabel rekapitulasi absensi karyawan bagian Instalasi \& Pengolahan PTPN X Pabrik Gula Lestari Kertosono tahun 2019 sebagai berikut:

Tabel 1. Rekapitulasi absensi karyawan bagian Instalasi \& Pengolahan tahun 2019

\begin{tabular}{lrrrr}
\hline \multicolumn{1}{c}{ Bulan } & Sakit & Izin & \multicolumn{2}{c}{ Tanpa } \\
& & \multicolumn{3}{c}{ Keterangan } \\
\hline November 2019 & 12 & 9 & 4 & $23,14 \%$ \\
Desember 2019 & 4 & 17 & 11 & $29,62 \%$ \\
Januari 2020 & 8 & 4 & 14 & $24,07 \%$ \\
Februari 2020 & 15 & 6 & 4 & $23,14 \%$ \\
\hline
\end{tabular}

Rendahnya ketidakhadiran karyawan dapat mempengaruhi hasil kerja dan produktifitas kerja karyawan. Adapun beberapa tujuan yang ingin dicapai dalam penelitian ini yaitu untuk mengetahui dan menganalisis secara parsial pengaruh motivasi kerja terhadap kinerja karyawan PTPN X Unit Pabrik Gula Lestari Kertosono, untuk mengetahui dan menganalisis secara parsial pengaruh disiplin kerja terhadap kinerja karyawan PTPN X Unit Pabrik Gula Lestari Kertosono, Untuk mengetahui dan menganalisis secara simultan pengaruh Motivasi dan disiplin kerja terhadap kinerja karyawan PTPN X Unit Pabrik Gula Lestari Kertosono.

\section{Tinjauan Pustaka \\ Z Motivasi Kerja}

Motivasi merupakan sesuatu hal yang menyebabkan, mendukung perilaku manusia supaya mau bekerja giat dan antusias mencapai hasil yang optimal. Menurut (Sinambela, 2017) berpendapat bahwa motivasi adalah serangkaian sikap dan nilai-nilai yang mempengaruhi individu untuk mencapai hal yang spesifik sesuai dengan tujuan individu. Sedangkan (Kasmir, 2018) berpendapat bahwa motivasi adalah hal yang menyebabkan, mendukung perilaku manusia supaya mau bekerja giat dan antusias mencapai hasil yang optimal.

Teori Motivasi (Hierarki Kebutuhan Maslow) Dalam Sinambela (Sinambela, 2017) menyebutkan hierarki kebutuhan manusia. Teori lima kebutuhan Hierarki Maslow yaitu sebagai berikut:

1. Kebutuhan Fisiologis, yaitu kebutuhan untuk makan, minum, perlindungan fisik, bernapas, seksual. Kebutuhan ini merupakan kebutuhan tingkat terendah atau disebut pula sebagai kebutuhan yang paling dasar.

2. Kebutuhan Rasa Aman, yaitu kebutuhan akan perlindungan diri dari ancaman, bahaya, pertentangan, dan lingkungan hidup. 
3. Kebutuhan Untuk Rasa Memiliki (Sosial), yaitu kebutuhan untuk diterima oleh kelompok, berafiliasi, berinteraksi, dan kebutuhan untuk mencintai serta dicintai.

4. Kebutuhan Akan Harga Diri, yaitu kebutuhan untuk dihormati dan dihargai oleh orang lain.

5. Kebutuhan Untuk Mengaktualisasikan Diri, yaitu kebutuhan untuk menggunakan kemampuan, skill dan potensi. Kebutuhan untuk berpendapat dengan mengemukakan ideide, gagasan dan kritik terhadap sesuatu.

Kesimpulannya motivasi merupakan kegiatan yang mengakibatkan, menyalurkan, memelihara dan mendorong perilaku manusia. Motivasi kerja dapat dilihat dari kuatnya keinginan memuaskan kebutuhan yang lebih tinggi apabila kebutuhan yang lebih rendah telah dipuaskan

\section{Displin Kerja}

Disiplin merupakan sikap hormat terhadap peraturan dan ketetapan perusahaan yang ada dalam diri karyawan yang menyebabkan ia dapat menyesuaikan diri dengan sukarela pada peraturan dan ketetapan perusahaan. Menurut Prawirosentono (1999) disiplin adalah taat kepada hukum dan peraturan yang berlaku. Menurut Sinambela (2018), disiplin merupakan sikap, tingkah laku dan perbuatan yang sesuai dengan peraturan perusahaan baik yangtertulis maupun yang tidak tertulis.

Menegakkan suatu kedisiplinan sangat penting bagi perusahaan, bagi organisasi adanya disiplin kerja akan menjamin terpeliharanya tata tertib dan kelancaran pelaksanaan tugas, sehingga diperoleh hasil yang optimal. Sedangkan bagi karyawan akan diperoleh suasana kerja yang menyenangkan sehingga akan menambah semangat kerja dalalm melaksanakan pekerjaannya. Disiplin kerja dapat membawa sesuatu yang memiliki manfaat besar. Adapun beberapa bentuk-bentuk displin kerja menurut (Sinambela, 2017) yaitu:

1. Disiplin Preventif. Merupakan suatu upaya untuk menggerakkan pegawai untuk mengikuti dan mematuhi pedoman kerja aturan-aturan yang telah digariskan oleh perusahaan

2. Disiplin Korektif. Merupakan suatu upaya untuk menggerakkan pegawai dalam suatu peraturan dan mengarahkan untuk tetap memenuhi peraturan yang sesuai dengan pedoman yang telah berlaku pada perusahaan

3. Disiplin Progresif. Merupakan kegiatan yang memberikan hukuman hukuman yang berat terhadap pelanggaran pelanggaran yang berulang

\section{Kinerja Karyawan}

Kinerja adalah hasil kerja yang dapat dicapai oleh seseorang atau kelompok orang dalam suatu perusahaan. Menurut (Kasmir, 2018) mengemukakan bahwa kinerja merupakan hasil kerja secara kualitas dan kuantitas yang dicapai oleh seorang karyawan dalam melaksanakan tugasnya sesuai dengan tanggung jawabnya. Menurut (Sinambela, 2017) mengemukakan bahwa kinerja (performance) adalah hasil pekerjaan yang dicapai oleh seseorang berdasarkan syarat-syarat pekerjaan atau job recruitment.

Menurut (Sugiono, 2018) Ada beberapa indikator dalam kinerja karyawan secara individu ada enam indikator, yaitu:

1. Kualitas. Kualitas kerja diukur dari persepsi karyawan terhadap kualitas pekerjaan yang dihasilkan serta kesempurnaan tugas.

2. Kuantitas. Merupakan jumlah yang dihasilkan dinyatakan dalam istilah seperti jumlah unit, jumlah siklus aktivitas yang diselesaikan.

3. Ketepatan Waktu. Merupakan tingkat aktivitas diselesaikan pada awal waktu yang dinyatakan, dilihat dari sudut koordinasi dengan hasil output serta memaksimalkan waktuyang tersedia untuk aktivitas lain.

4. Efektivitas. Merupakan tingkat penggunaan sumber daya organisasi (tenaga, uang, teknologi, bahan baku) dimaksimalkan dengan maksud menaikkan hasil dari setiap unit dalam penggunaan sumber daya. 
Sehingga kinerja karyawan adalah prestasi atau hasil kerja yang dihasilkan oleh kemampuan dari individu atau kelompok yang dilakukan berdasarkan kecakapan, pengalaman, kesanggupan, dan waktu dengan maksimal.

\section{Model Hipotesis}

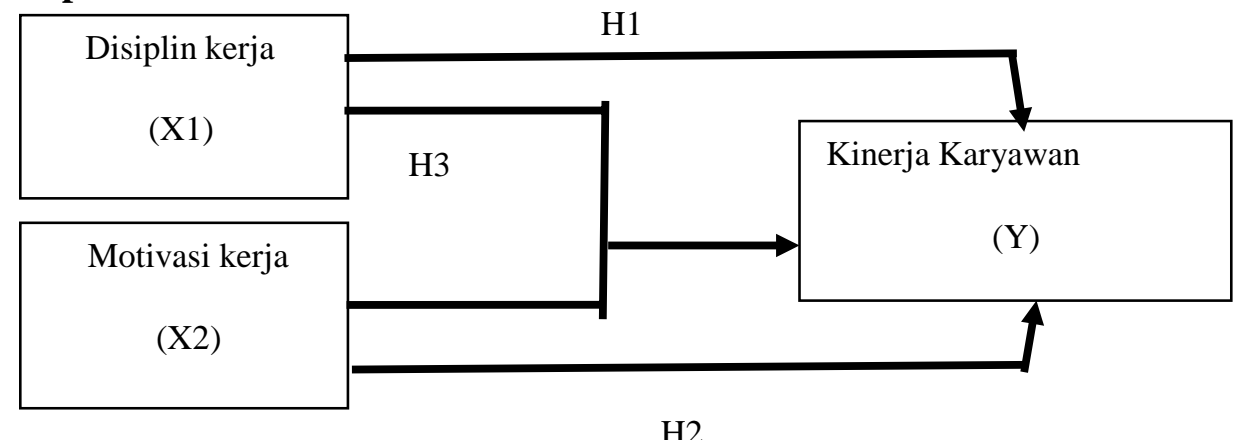

Berdasarkan model hipotesis, maka hipotesis dalam penelitian ini adalah:

H1 : Variabel Motivasi Kerja secara parsial berpengaruh signifikan terhadap Kinerja Karyawan. H2 : Variabel Disiplin Kerja secara parsial berpengaruh signifikan terhadap Kinerja Karyawan. H3 : Variabel Motivasi Kerja dan Disiplin Kerja secara simultan berpengaruh signifikan terhadap Kinerja Karyawan

\section{METODE PENELITIAN}

\section{Jenis Dan Lokasi Penelitian}

Jenis penelitian menggunakan penelitian penjelasan (explanatory research) dengan pendekatan deskriptif kuantitatif yaitu penelitian tentang data yang dikumpulkan dan dinyatakan dalam bentuk angka-angka, dan dilakukan di PTPN X Pabrik Gula Lestari Kertosono Bagian Instalasi Dan Pengolahan. Lokasi perusahaan ini terletak di Jalan Raya Lestari, Ngrombot, Kec. Patianrowo, Kertosono, Jawa Timur 64391.

\section{Populasi Sampel}

Dalam penelitian ini yang menjadi populasi adalah seluruh karyawan PTPN X Pabrik Gula Lestari Kertosono Pada bagian Instansi \& Pengolahan dengan jumlah 68 karyawan. Teknik sampling yang digunakan adalah sampel sampling jenuh yaitu seluruh karyawan Bagian Instalasi Dan Pengolahan PTPN X Pabrik Gula Lestari Kertosono.

\section{Pengumpulan Data}

Pengumpulan data penelitian ini menggunakan metode kuesioner yang terdiri dari beberapa pertanyaan yang berasosiasi dengan variabel yang diteliti dan menggunakan metode dokumentasi dari data perusahaan. Dan menggunakan observasi yaitu melakukan pengamatan secara langsung pada objek penelitian.

\section{Metode Analisis DataAnalisis Deskriptif}

Statitik deskriptif digunakan untuk memberikan diskripsi data dari variabel motivasi kerja, disiplin kerja dan kinerja karyawan, serta butir butir yang didistribusikan dari masingmasing variabel.

\section{Analisis Inferensial}

Analisis Inferensial yang digunkan dalam penelitian ini regresi linier berganda yang didalam menyangkut uji $\mathrm{t}$ dan uji $\mathrm{F}$. Analisis regresi linier berganda yaitu untuk mengukur seberapa jauh pengaruh disiplin kerja (X1) dan motivasi kerja (X2) terhadap kinerja karyawan (Y). 


\section{HASIL DAN PEMBAHASAN}

\section{Analisis Statistik Deskriptif}

Data yang diperoleh dari jawaban responden melalui kuesioner dapat dilihat pada tabel sebagai berikut:

a) Motivasi Kerja (X1).

Distribusi Frekuensi untuk variabel Motivasi Kerja (X1) disajikan pada tabel berikut:

Tabel 1. Hasil Kuesioner Variabel Motivasi (X1)

\begin{tabular}{|c|c|c|c|c|c|}
\hline \multirow[t]{2}{*}{ Pernyataan } & \multicolumn{5}{|c|}{ Skor } \\
\hline & SS & $S$ & $\mathrm{~N}$ & TS & STS \\
\hline $\begin{array}{l}\text { Gaji yang diberikan telah mampu memenuhi } \\
\text { kebutuhan hidup saya }\end{array}$ & 5 & 23 & 10 & 35 & 0 \\
\hline Presentase & $7 \%$ & $33 \%$ & $14 \%$ & $51 \%$ & $0 \%$ \\
\hline $\begin{array}{l}\text { Perusahaan menciptakan kondisikerja yang aman } \\
\text { dan nyaman }\end{array}$ & 10 & 1 & 25 & 30 & 2 \\
\hline Presentase & $14 \%$ & $2 \%$ & $36 \%$ & $44 \%$ & $4 \%$ \\
\hline $\begin{array}{l}\text { Saya lebih menikmati bekerja dengan orang lain } \\
\text { daripada bekerjasendiri }\end{array}$ & 10 & 2 & 25 & 30 & 1 \\
\hline Presentase & $14 \%$ & $4 \%$ & $36 \%$ & $44 \%$ & $2 \%$ \\
\hline $\begin{array}{l}\text { Perusahaan memberikan penghargaan kepada } \\
\text { karyawan yangberprestasi dan memiliki kinerja } \\
\text { baik. }\end{array}$ & 8 & 15 & 5 & 35 & 5 \\
\hline Presentase & $11 \%$ & $22 \%$ & $7 \%$ & $51 \%$ & $7 \%$ \\
\hline $\begin{array}{l}\text { Pemberian prestasi tidak memberikan dorongan } \\
\text { dalambekerja }\end{array}$ & 5 & 15 & 1 & 45 & 2 \\
\hline Presentase & $7 \%$ & $22 \%$ & $2 \%$ & $66 \%$ & $4 \%$ \\
\hline
\end{tabular}

Tabel 1 Motivasi Kerja (X1) menunjukkan bahwa 51 persen dari 68 karyawan atau 35 karyawan mengatakan "Tidak Setuju" bahwa karyawan bagian Instansi \& Pengolahan PTPN X Pabrik Gula Lestari Kertosono tidak mendapatkan gaji yang cukup untuk memenuhi kebutuhan hidup mereka. Sehingga hal tersebut yang menyebabkan rendahnya tingkat motivasi karyawan terhadap perusahaan.

Motivasi Kerja (X1) menunjukkan bahwa 44 persen dari 68 karyawan atau 30 karyawan menyatakan "Tidak Setuju" bahwa karyawan dibagian Instansi \& Pengolahan PTPN X Pabrik Gula Lestari Kertosono tidak bisa menciptakan kondisi kerja yang aman dan nyaman oleh karena itulah karyawan mempuyai kerendahan motivasi saat bekerja.

Motivasi Kerja (X1) menunjukkan bahwa 44 persen dari 68 karyawan atau 30 karyawan, menyatakan "Tidak Setuju" hal ini terbukti bahwa karyawan bagian Instalasi \& Pengolahan PTPN X Pabrik Gula Lestari Kertosono, mempunyai tingkat kerendahan motivasi kerja yang disebabkan karena tidak nyamanya karyawan dengan karyawan yang lain yang mana antar karyawan ingin menjadi unggul di hadapan supervisi atau atasan dengan tidak memperhatikan kepentingan rekan kerja yang lain artinya mereka lebih menyukai melakukan pekerjaan secara sendiri-sendiri.

Motivasi Kerja (X1) menunjukkan bahwa 66 persen dan 51 persen dari 68 karyawan atau 45 dan 35 karyawan menyatakan "Tidak Setuju" bahwa karyawan bagian Instalasi \& Pengolahan mendapatkan penghargaan pada karyawan yang berprestasi, karena perusahaan sendiri tidak mampu dan jarang memberikan penghargaan atau melakukan promosi jabatan walaupun karyawan sudah bekerja secara maksimal kepada perusahaan. 
b) Variabel Disiplin Kerja (X2).

Distribusi Frekuensi untuk variabel Disiplin Kerja (X2) disajikan pada tabel berikut:

Tabel 2. Hasil Kuesioner Variabel Displin Kerja (X2)

\begin{tabular}{lccccc}
\hline \multicolumn{1}{c}{ Pernyataan } & \multicolumn{3}{c}{ Skor } \\
\cline { 2 - 5 } & $\mathrm{SS}$ & $\mathrm{S}$ & $\mathrm{N}$ & $\mathrm{TS}$ & $\mathrm{STS}$ \\
\hline Saya selalu hadir tepat waktu saatbekerja & 5 & 17 & 10 & 35 & 1 \\
Presentase & $7 \%$ & $25 \%$ & $14 \%$ & $51 \%$ & $2 \%$ \\
$\begin{array}{l}\text { Saya mampu menyelesaikan pekerjaan dengan } \\
\text { tepat waktu }\end{array}$ & 10 & 1 & 25 & 30 & 1 \\
$\begin{array}{l}\text { Presentase } \\
\text { Saya melaksanakan pekerjaan sudah sesuai }\end{array}$ & $14 \%$ & $2 \%$ & $36 \%$ & $44 \%$ & $2 \%$ \\
dengan prosedur kerja & 6 & 45 & 13 & 2 & 2 \\
yang telah ditetapkan olehperusahaan & & & & & \\
$\begin{array}{l}\text { Presentase } \\
\text { Saya memiliki etika yang baikselama berada di } \\
\text { kantor }\end{array}$ & $5 \%$ & $66 \%$ & $19 \%$ & $4 \%$ & $4 \%$ \\
$\begin{array}{l}\text { Presentase } \\
\text { Saya memiliki sikap patuh terhadapsemua }\end{array}$ & $7 \%$ & $22 \%$ & $2 \%$ & $66 \%$ & $4 \%$ \\
peraturan yang berlaku & 8 & 15 & 5 & 35 & 5 \\
Presentase & & & & & \\
\end{tabular}

Tabel 1 menunjukkan bahwa 51 persen dari 68 karyawan atau 35 karyawan mengatakan "Tidak setuju". Bahwa karyawan PTPN X Pabrik Gula Lestari Kertosono bagian Instalasi \& Pengolahan tidak selalu taat terhadap peraturan waktu serta mampu menyelesaikan pekerjaan dengan tepat waktu.

Displin Kerja (X2) menunjukkan bahwa 44 persen dari 68 karyawan atau 30 karyawan menyatakan "Tidak Setuju" bahwa karyawan PTPN X Pabrik Gula Lestari Kertosono bagian Instalasi \& Pengolahan tidak mampu untuk menyelesaikan pekerjaan sesuai dengan prosedur yang ditetapkan perusahaan.

Displin Kerja (X2) menunjukkan bahwa 66 persen dari 68 karyawan atau 45 karyawan menyatakan "Setuju" bahwa karyawan PTPN X Pabrik Gula Lestari Kertosono bagian Instalasi \& Pengolahan mampu untuk menyelesaikan pekerjaan sesuai dengan prosedur yang ditetapkan perusahaan.

Displin Kerja (X2) menunjukkan bahwa 66 persen dan 51 persen dari 68 karyawan atau 45 dan 35 karyawan menyatakan "Tidak setuju". Karyawan bagian Instalasi \& Pengolahan, PTPN X Pabrik Gula Lestari Kertosono yang menyebabkan tingkat disiplin kerja rendah yaitu karena menurut mereka peraturan yang ditetapkan oleh perusahaan tidak berpengaruh apapun kepada mereka, tidak ada kosekuensi atau hukumannya.

c) Variabel Kinerja Karyawan (Y)

Definisi Kinerja Karyawan (Y) yang merupakan variabel terikat dalam penelitian dengan beberapa indikator:

Tabel 3. Hasil Kuesioner Variabel Kinerja Karyawan (Y)

\begin{tabular}{|c|c|c|c|c|c|}
\hline \multirow[t]{2}{*}{ Pernyataan } & \multicolumn{5}{|c|}{ Skor } \\
\hline & SS & $\mathrm{S}$ & $\mathrm{N}$ & TS & STS \\
\hline $\begin{array}{l}\text { Standar kualitas yang telah ditetapkan oleh instansi } \\
\text { selama ini dapat saya capai dengan baik }\end{array}$ & 6 & 1 & 20 & 40 & 1 \\
\hline PRESENTASE & $8 \%$ & $2 \%$ & $29 \%$ & $58 \%$ & $2 \%$ \\
\hline $\begin{array}{l}\text { Tingkat pencapaian volume kerjayang saya hasilkan } \\
\text { telah sesuai dengan harapan perusahaan }\end{array}$ & 5 & 16 & 45 & 1 & 1 \\
\hline PRESENTASE & $7 \%$ & $23 \%$ & $66 \%$ & $2 \%$ & $2 \%$ \\
\hline $\begin{array}{l}\text { Seluruh tugas pekerjaan selama ini dapat saya } \\
\text { kerjakan dan hasilnya sesuai dengan waktu yang telah } \\
\text { direncanakan instansi }\end{array}$ & 1 & 1 & 15 & 50 & 1 \\
\hline PRESENTASE & $2 \%$ & $2 \%$ & $22 \%$ & $73 \%$ & $2 \%$ \\
\hline
\end{tabular}




\begin{tabular}{lccccc}
\hline \multirow{2}{*}{ Pernyataan } & \multicolumn{3}{c}{ Skor } & \\
\cline { 2 - 5 } & $\mathrm{SS}$ & $\mathrm{S}$ & $\mathrm{N}$ & $\mathrm{TS}$ & $\mathrm{STS}$ \\
\hline Saya mampu bekerjasama yangbaik dengan teamwork & 6 & 2 & 14 & 45 & 1 \\
Presentase & $8 \%$ & $4 \%$ & $20 \%$ & $66 \%$ & $2 \%$ \\
$\begin{array}{l}\text { Saya senang membantu rekankerja yang kesulitan } \\
\text { dalam bekerja }\end{array}$ & 4 & 2 & 10 & 50 & 2 \\
Presentase & $5 \%$ & $4 \%$ & $14 \%$ & $73 \%$ & $4 \%$ \\
\hline
\end{tabular}

Tabel 4 menunjukkan bahwa 58 persen dari 68 karyawan atau 40 karyawan mengatakan "Tidak Setuju" bahwa karyawan bagian Instalasi \& Pengolahan belum mendapatkan standar kualitas yang telah ditetapkan oleh perusahaandengan baik. Kinerja Karyawan (Y) menunjukan bahwa 66 persen dari 68 karyawan atau 45 karyawan menyatakan "Netral" belum sebagian karyawan yang mampu untuk menyelesaikan pekerjaan dengan rasa penuh tanggung jawab.

Kinerja Karyawan (Y) menunjukkan bahwa 73 persen dari 68 karyawan atau 50 karyawan menyatakan "Tidak Setuju" hal ini terbukti bahwa menurunnya kinerja karyawan disebabkan karena adanya ketidaksesuaian jam kerja, dimana sering terjadi pelanggaran jam kerja. Kinerja Karyawan (Y) menunjukkan bahwa 73 persen dan 66 persen dari 68 karyawan atau 50 dan 45 karyawan menyatakan "Tidak Setuju" bahwa belum mampu bekerjasama yang baik dengan teamwork, karena mereka cenderung ingin menonjolkan dirinya masing-masing. Sehingga mereka tidak bisa saling membantu satu sama lain apabila salah satu rekannya mendapatkan kesulitan.

\section{Hasil Analisis Regresi Linier Berganda}

Hasil perhitungan analisis regresi linier berganda diperoleh hasil seperti di bawah ini:

Tabel 4. Hasil Perhitungan Analisis Regresi Linier Berganda

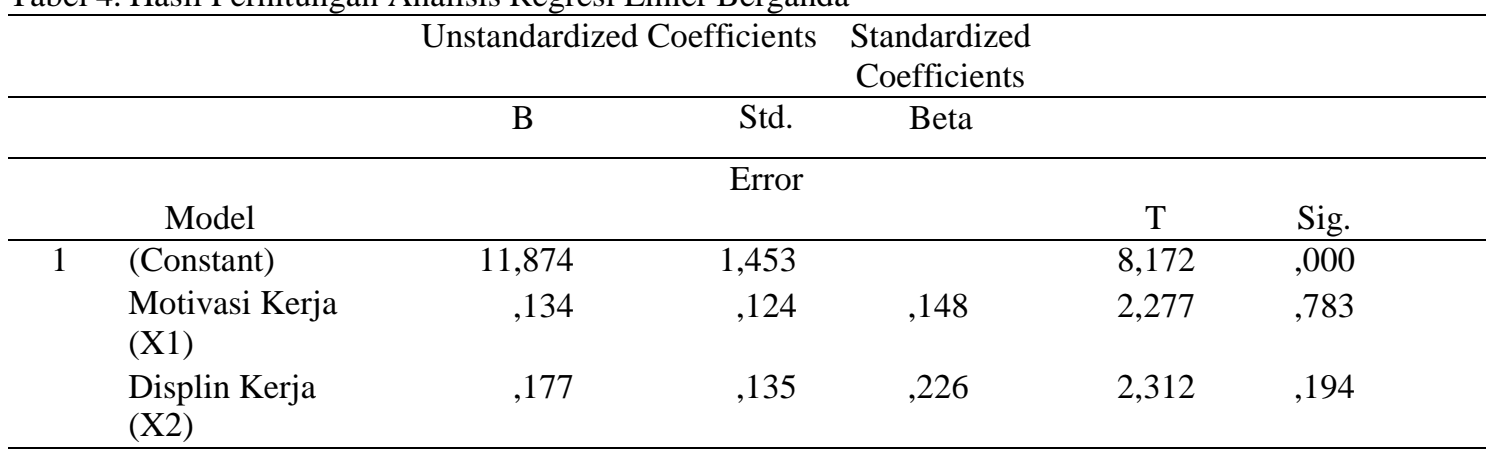

a. Dependent Variable: Kinerja Karyawan

Sumber: SPSS 24

Analisis ini digunakan untuk mengetahui besarnya pengaruh dua variabel bebas. Berdasarkan hasil perhitungan tersebut diatas, diperoleh persamaan regresi linier berganda sebagai berikut:

$$
\begin{aligned}
\mathbf{Y} & =\mathbf{a}+\mathbf{b} 1 \mathrm{X} 1+\mathbf{b} 2 \mathrm{X} 2 \\
& =11,874+0,134 \mathrm{X} 1+\mathbf{0 , 1 7 7} \mathrm{X} 2
\end{aligned}
$$

1. Konstanta (a) yang dihasilkan sebesar 11,874 menunjukkan bahwa peningkatan nilai Kinerja Karyawan (Y) sebesar 0,134 jika Kinerja karyawan bagian instansi \& pengolahan PTPN X Pabrik Gula Lestari Kertosono yang terdiri dari Motivasi Kerja (X1) dan DisplinKerja (X2).

2. Nilai koefisien Motivasi Kerja (b1) sebesar 0,134 menunjukkan bahwa jika variabel Motivasi Kerja (X1) ditingkatkan, maka akan mengakibatkan peningkatan Kinerja Karyawan (Y) sebesar 0,134 dengan asumsi variabel lain konstanta.

3. Nilai koefisien Displin Kerja (b2) sebesar 0,177 menunjukkan bahwa jika variabel Displin Kerja (X2) ditingkatkan, maka akan mengakibatkan peningkatan Kinerja Karyawan (Y) sebesar 0,177 dengan asumsi variabel lain konstanta. 


\section{Hasil Uji Hipotesis}

\section{a) $\mathbf{U j i ~} \mathbf{t}$}

Uji t digunakan untuk menguji hipotesis digunakan uji t yang menunjukkan pengaruh secara parsial atau secara signifikan dari masing-masing variabel bebas terhadap variabel independen. Hasil Uji t variabel Motivasi Kerja (X1) terhadap Kinerja Karyawan (Y) dengan $\mathrm{t}$ hitung $=2,277$, sedangkan $\mathrm{t}$ tabel $=1$, 998. Karena $\mathrm{t}$ hitung $>\mathrm{t}$ tabel yaitu 2,277 > 1,998 atau nilai sig $\mathrm{t}(0,000)<\alpha=0.05$. Maka kesimpulannya secara parsial variabel Motivasi Kerja (X1) mempunyai pengaruh signifikansi secara parsial terhadap Kinerja Karyawan (Y).

Hasil uji t Variabel Disiplin Kerja (X2) terhadap Kinerja Karyawan (Y) menunjukkan $\mathrm{t}$ hitung sebesar 2,312 dengan $\mathrm{t}$ tabel sebesar 1,998. Karena $\mathrm{t}$ hitung $>\mathrm{t}$ tabel yaitu 2,312 > 1,998 atau nilai sig $\mathrm{t}(0,000)<\alpha=0.05$. Maka Maka kesimpulannya secara parsial variabel Displin Kerja (X2) mempunyai pengaruh signifikansi secara parsial terhadap Kinerja Karyawan (Y).

a) Uji F

Hasil $\mathrm{F}$ hitung sebesar 1,287, sedangkan $\mathrm{F}$ tabel sebesar 3,14. Karena $\mathrm{F}$ hitung $>\mathrm{F}$ tabel yaitu 1,287 $>3,14$ atau nilai sig $\mathrm{F}(0,000)<\alpha=0,05$. Maka model analisis regeresi adalah signifikan. Hal ini antara variabel Motivasi Kerja (X1) dan Disiplin Kerja (X2) secara simultan berpengaruh terhadap Kinerja Karyawan (Y).

\section{Pembahasan}

\section{Analisis Deskriptif}

a) Analisis Deskriptif Motivasi Kerja

Berdasarakan analisis deskriptis Motivasi Kerja (X1) dapat dilihat dari setiap pernyataan bahwa mereka mengatakan tidak setuju. Dengan Indikator motivasi kerja memiliki rata-rata item yang tertinggi yaitu sebesar, (66 persen atau 45 karyawan) hal ini menunjukkan responden tidak setuju jika perusahaan tidak memberikan prestasi dalam bekerja, karena mereka menggap prestasi akan memberikan dorongan untuk bekerja pada PTPN X Pabrik Gula Lestari. Indikator yang terendah yaitu sebesar (44 persen atau 30 karyawan) hal ini menunjukkan responden tidak setuju pada indikator bahwa perusahaan perusahaan menciptakan kondisi kerja yang aman dan nyaman.

Sehingga kesimpulannya motivasi kerja kurang diterapkan pada PTPN X Pabrik Gula Lestari hal ini karena banyak sekali karyawan yang memilih tidak setuju. Mereka merasa bahwa perusahaan belum mampu untuk menghasilkan kondisi kerja yang aman dan nyaman. Hal tersebut didukung oleh Teori Motivasi Hierarki Maslow, kebutuhan dasar yang harus dipenuhi perusahaan yaitu kebutuhan fisiologis, kebutuhan akan keselamatan dan keamanan, kebutuhan akan kebersamaan, kasih sayang, dan kebutuhan akan aktualisasi diri. (Gardjito, 2014)

b) Analisis Deskriptif Disiplin Kerja

Berdasarkan analisis deskriptif, variabel Disiplin Kerja (X2) dapat dilihat dari setiap pernyataan bahwa mereka mengatakan tidak setuju dan setuju. Sehingga sebesar (66 persen atau 45 Karyawan) karyawan setuju bahwa merek sudah melaksanakan pekerjaan sesuai dengan prosedur kerja yang ditetapkan oleh perusahaan Dan Indikator yang terendah memiliki rata-rata sebesar (44 persen atau 30 karyawan), hal ini menunjukkan PTPN X Pabrik Gula Lestari tidak setuju mengenai penyelesaian tugas secara tepat waktu.

Sehingga kesimpulannya masih terdapat kesenjangan dalam displin kerja karyawan bagian instalasi dan pengolahan PTPN X Pabrik Gula Lestari Kertosono. Dimana menurut mereka peraturan yang ditetapkan oleh perusahaan tidak ada kosekuensi atau hukumannya, sehingga mereka selalu melaksanakan tugas sesuai dengan prosedur kerja yang ditetapkan perusahaan akan tetapi dalam penyelesaian tugas selalu tidak tepat waktu. Dalam kenyataannya kedisiplinan karyawan didalam karyawan itu sangatlah penting dan kedisiplinan dalam suatu organisasi dapat ditegakkan bilamana sebagian besar peraturanperaturannya ditaati para anggota organisasi tersebut (Edy, 2018) 
c) Analisis Deskriptif Kinerja Karyawan

Berdasarkan analisis deskriptif, variabel kinerja karyawan (Y) dapat dilihat dari setiap pernyataan bahwa mereka mengatakan tidak setuju. Berdasarkan nilai $(73$ persen atau 50 karyawan). memiliki item yang tertinggi. Hal ini menunjukkan bahwa efektifitas pekerjaan yang tidak mampu diselesaikan oleh karyawan pada PTPN X Pabrik Gula Lesari dengan baik. Indikator yang terendah sebesar (58 persen atau 40 karyawan), hal ini menunjukkan bahwaTingkat pencapaian volume kerja yang dihasilkan karyawan PTPN X Pabrik Gula Lestari tidak sesuai dengan harapan perusahaan.

Sehingga kesimpulannya masih terdapat permasalahan dalam kinerja karyawan bagian instalasi dan pengolahan PTPN X Pabrik Gula Lestari Kertosono. Menurut mereka menurunnya kinerja mereka disebabkan karena adanya ketidaksesuaian jam kerja, dimana sering terjadi pelanggaran jam kerja. Dan mereka belum mampu bekerjasama yang baik dengan teamwork, karena cenderung ingin menonjolkan dirinya masing-masing. Dan permasalah ini didukung oleh teori Amstrong yang mengatakan bahwa manajemen kinerja adalah cara untuk memberikan pendekatan yang lebih terintegrasi dan berkelanjutan. Sehingga hal yang perlu dilakukan oleh pemimpin perusahaan adalah dengan memberikan pendekatan melalui motivasi karyawan agar mau bekerja secara bersama-sama dan menegakkan peraturan yang harus dipatuhi semua karyawan, sehingga dengan demikian harapannya perusahaan dapat menjalankan kegiatan operasi perusahaan tanpa adanya permasalahan dan tujuan perusahaan akan lebih mudah tercapai.

\section{Analisis Inferensial}

a) Pengaruh Motivasi Kerja (X1) Terhadap Kinerja Karyawan (Y)

Berdasarkan hasil pengujian hipotesis yang telah dilakukan peneliti, dapat diketahui bahwa motivasi kerja berpengaruh secara signifikan terhadap kinerja karyawan. Hasil Uji t variabel Motivasi Kerja (X1) terhadap Kinerja Karyawan (Y) dengan t hitung $=2,277$, sedangkan $\mathrm{t}$ tabel $=1$, 998. Karena $\mathrm{t}$ hitung $>\mathrm{t}$ tabel yaitu 2,277 $>1,998$ atau nilai sig $\mathrm{t}$ $(0,000)<\alpha=0,05$. Maka kesimpulannya secara parsial variabel Motivasi Kerja (X1) mempunyai pengaruh signifikansi secara parsial terhadap Kinerja Karyawan (Y). Hasil penelitian ini didukung oleh pendapat (Setiaji, 2019) berpendapat bahwa motivasi adalah hal yang menyebabkan, mendukung perilaku manusia supaya mau bekerja giat dan antusias mencapai hasil yang optimal.

Hal ini dapat diartikan bahwa menurut (Edy, 2018) motivasi berperan penting dalam mendukung perilaku manusia dalam bekerja, motivasi bisa berasal dari dalam diri maupun dalam ruang lingkup perusahaan. Dari dalam diri berkaitan dengan keinginan untuk menaiki jabatan maupun mencapai prestasi dalam bekerja, lalu dari lingkup perusahaan berasal dari lingkungan perusahaan, rekan kerja, fasilitas penunjang pekerjaan, maupun bentuk penghargaan lainnya.

b) Pengaruh Disiplin Kerja (X2) Terhadap Kinerja Karyawan (Y)

Berdasarkan hasil pengujian hipotesis yang dilakukan peneliti, dapat diketahui bahwa disiplin kerja berpengaruh secara signifikan terhadap kinerja karyawan. Hal ini dapat dibuktikan dengan Hasil uji t Variabel Disiplin Kerja (X2) terhadap Kinerja Karyawan (Y) menunjukkan $\mathrm{t}$ hitung sebesar 2,312 dengan $\mathrm{t}$ tabel sebesar 1,998. Karena $\mathrm{t}$ hitung $>\mathrm{t}$ tabel yaitu 2,312 $>1,998$ atau nilai sig $\mathrm{t}(0,000)<\alpha=0,05$. Maka Maka kesimpulannya secara parsial variabel Displin Kerja (X2) mempunyai pengaruh signifikansi secara parsial terhadap Kinerja Karyawan (Y).

Hasil penelitian ini didukung oleh pendapat (Irwanto \& Melinda, 2017), disiplin kerja dapat membawa sesuatu yang memiliki manfaat besar yaitu untuk karyawan, menjadi lebih produktif lagi sehingga akan menguntungkan dalam jangka waktu yang panjang. 
c) Pengaruh Motivasi Kerja (X1) dan Disiplin Kerja (X2) Terhadap Kinerja Karyawan (Y)

Berdasarkan hasil pengujian yang dilakukan peneliti, dapat diketahui bahwa motivasi kerja dan disiplin kerja secara simultan berpengaruh secara signifikan terhadap kinerja karyawan. Hal dapat dibuktikan melalui Hasil $\mathrm{F}$ hitung sebesar 1,287, sedangkan $\mathrm{F}$ tabel sebesar 3,14. Karena $\mathrm{F}$ hitung $>\mathrm{F}$ tabel yaitu $1,287>3,14$ atau nilai sig $\mathrm{F}(0,000)<\alpha=$ 0,05. Maka model analisis regeresi adalah signifikan. Hal ini antara variabel Motivasi Kerja (X1) dan Disiplin Kerja (X2) secara simultan berpengaruh terhadap Kinerja Karyawan (Y).

Hasil penelitian ini didukung (Kasmir 2018:182) mengemukakan bahwa kinerja merupakan hasil kerja secara kualitas dan kuantitas dalam melaksanakan tugasnya. Sehingga kinerja adalah hasil kerja yang dihasilkan oleh kemampuan dari individu atau kelompok yang dilakukan berdasarkan kecakapan, pengalaman, kesanggupan, dan waktu dengan maksimal, yang dapat dicapai oleh seseorang atau kelompok orang dalam suatu perusahaan.

\section{KESIMPULAN}

Berdasarkan hasil analisis dan pembahasan yang diuraikan pada PTPN X Pabrik Gula Lestari (Kertosono), maka dapat ditarik kesimpulan sebagai berikut; variabel bebas Motivasi Kerja (X1) dan Displin Kerja (X2) berpengaruh secara simultan terhadap variabel terikat Kinerja Karyawan (Y) yang diperoleh Fhitung lebih besar dari Ftabel sehingga dapat diambil kesimpulan bahwa semua variabel Motivasi Kerja (X1) dan Displin Kerja (X2) berpengaruh secara signifikan terhadap variabel terikat Kinerja Karyawan (Y) di bagian Instansi \& Pengolahan PTPN X Pabrik Gula Lestari Kertosono. Hasil pengujian secara parsial menyimpulkan bahwa variabel Motivasi Kerja (X1) danvariabel Displin Kerja (X2) sama sama berpengaruh signifikan terhadap variabelKinerja Karyawan (Y).

\section{DAFTAR PUSTAKA}

Edy, S. (2018). Manajemen Sumber Daya Manusia. Jakarta: Kencana Prenada Media Group, Gardjito, A. (2014). Pengaruh Motivasi Kerja Dan Lingkungan Kerja Terhadap Kinerja Karyawan (Studi Pada Karyawan Bagian Produksi PT. Karmand Mitra Andalan Surabaya). Jurnal Administrasi Bisnis S1 Universitas Brawijaya, 13(1), 83778.

Irwanto, T., \& Melinda, T. F. (2017). Pengaruh Disiplin Dan Motivasi Dan Kinerja Pegawai Dinas Peternakan Dan Kesehatan Hewan Provinsi Bengkulu. Ekombis Review, 215-228.

Kasmir. (2018). Manajemen Sumber Daya Manusia (Teori Dan Praktik). Jakarta: PT Raja Grafindo Persada.

Prawirosentono, S. (1999). Kebijakan Kinerja Karyawan. Yogyakarta: BPFE.

Setiaji, B. (2019). Pengaruh Motivasi, Kepuasan, Dan Disiplin Kerja Terhadap Kinerja Karyawan (Studi Kasus Di Lingkungan Pegawai Kantor PDAM Kota Surakarta). Jurnal Manajemen.

Sinambela, L., P. (2017). Manajemen Sumber Daya Manusia. Cetakan ke. edited by S.(Editor) and R. D. (Editor). Jakarta: Bumi Aksara.

Sugiono. (2018). Metode penelitian pendidikan:(pendekatan kuantitatif, kualitatif dan $R \& D$ ). Bandung: Alfabeta. 